Article

\title{
Biomimetic Mineralization of Cytochrome $c$ Improves the Catalytic Efficiency and Confers a Functional Multi-Enzyme Composite
}

\author{
Xiao-Qing Gong ${ }^{1}$, Chuan-Wan Wei ${ }^{1}$, Jia-Kun $\mathrm{Xu}^{2}{ }^{2}$, Xiao-Juan Wang ${ }^{1, *}$, Shu-Qin Gao ${ }^{3}$ and \\ Ying-Wu Lin 1,3,4,* \\ 1 School of Chemistry and Chemical Engineering, University of South China, Hengyang 421001, China \\ 2 Key Lab of Sustainable Development of Polar Fisheries, Yellow Sea Fisheries Research Institute, \\ Chinese Academy of Fishery Sciences; Laboratory for Marine Drugs and Byproducts of Pilot National Lab \\ for Marine Science and Technology, Qingdao 266071, China \\ 3 Laboratory of Protein Structure and Function, University of South China, Hengyang 421001, China \\ 4 Hunan Key Laboratory for the Design and Application of Actinide Complexes, University of South China, \\ Hengyang 421001, China \\ * Correspondence: wxj0207@126.com (X.-J.W.); linlinying@hotmail.com or ywlin@usc.edu.cn (Y.-W.L.); \\ Tel.: +86-743-8578079 (X.-J.W.); +86-734-8282375 (Y.-W.L.)
}

Received: 4 July 2019; Accepted: 25 July 2019; Published: 29 July 2019

\begin{abstract}
The encapsulated enzyme system by metal-organic frameworks (MOFs) exhibits great potential in biofuel cells, pharmaceuticals, and biocatalysis. However, the catalytic efficiency and the enzymatic activity are severely hampered due to enzyme leaching and deficiency of storage stability. In this study, we immobilized cytochrome $c$ (Cyt $c$ ) into dimethylimidazole-copper $\left(\mathrm{Cu}(\mathrm{Im})_{2}\right)$ by biomimetic mineralization, and constructed a bioinorganic hybrid material, termed $\mathrm{Cyt} c @ \mathrm{Cu}(\operatorname{Im})_{2}$. Encapsulated $\mathrm{Cyt} c$ in $\mathrm{Cu}(\mathrm{Im})_{2}$ with a nanosheet structure exhibited significantly improved catalytic efficiency, enzymatic activity and kinetic performance. The catalytic efficiency $\left(k_{\mathrm{cat}} / K_{\mathrm{m}}\right)$ for Cyt $c @ \mathrm{Cu}(\operatorname{Im})_{2}$ was $\sim 20$-fold higher compared to that of free Cyt $c$. Moreover, the increased activity was not affected by long-term storage. Based on this system, we further constructed a multi-enzyme composite with glucose-oxidase (GOx), termed GOx-Cyt $c @ \mathrm{Cu}(\mathrm{Im})_{2}$, which exhibited greatly improved enzymatic activity, stability, and excellent selectivity for the detection of low concentrations of glucose. This strategy may provide new insights into the design of enzymes with high activity and stability, as well as the construction of multi-enzyme systems.
\end{abstract}

Keywords: enzymatic immobilization; biomimetic mineralization; multi-enzyme; bioinorganic hybrid material; biosensors

\section{Introduction}

Enzymes have been widely applied as catalysts inbiological systems and chemical systems, in an efficient and green manner [1-4]. Compared to synthetic catalysts, enzymes are often of high selectivity (i.e., chemo-, region-, stereo-) and minimal by-product generation [5-8]. However, the instability and poor reusability of natural enzymes restrict their potential applications. Enzyme encapsulation within a protective shell is a simple and efficient method to improve the stability and reusability of naturalenzymes [9-11]. Metal-organic frameworks (MOFs) are usually constructed by linking organic small molecules and metal ions, which can offer superior thermal and chemical protection for biomacromolecules such as proteins, as compared to other materials such as mesoporous silica and calcium carbonate [12]. However, MOFs usually possess a pore with dimensionssignificantly smaller than those of biomacromolecules, which may block the mass transfer of the enzyme and decrease the 
enzymatic activity $[13,14]$. Therefore, a general method to allow biomacromolecules to fully display their biological functions is still a challenge in the field of enzyme immobilization. Natural organisms have developed bio-mineralization strategies to deposit minerals in their structural frameworks. The bio-minerals can both provide effective stabilization for embedded enzymes and allow them to fully display biological functions [15-19]. Inspired by the sophisticated bio-inorganic hybrid structures in nature, it is desirable to prepare enzyme-inorganic mineral hybrid composites with both high enzyme activity and stability by biomimetic mineralization.

Cytochrome $c$ (Cyt $c$ ), as a model enzyme, is widely used in the field of biochemical analysis [20-23], as well as for the preparation of enzyme-MOF composites, due to its inherent peroxidase activity $[16,24-26]$. Therefore, we aimed to construct a Cyt $c$-MOF analog by biomimetic mineralization to obtain an efficient catalytic activity and stability. Moreover, multi-enzyme systems are a series of cascade enzymatic reactions completed by the synergistic effect of multiple enzymes, which have attracted great attention in recent years because of their important applications, such as in biosensors [27,28], biocatalysis [29,30], and pharmaceuticals, etc. [31,32].

As shown in this study, we constructed Cyt $c @ \mathrm{Cu}(\operatorname{Im})_{2}$ by biomineralization of Cyt $c$ into dimethylimidazole-copper $\left(\mathrm{Cu}(\mathrm{Im})_{2}\right)$. The assembly of $\mathrm{Cyt} c$ and glucose-oxidase (GOx) formed a multi-enzyme of GOx and Cyt $c$ encapsulated into $\mathrm{Cu}(\operatorname{Im})_{2}$. The prepared $\mathrm{Cyt} c @ \mathrm{Cu}(\mathrm{Im})_{2}$ composite exhibited an excellent stability and catalytic efficiency. Moreover, the encapsulated multi-enzyme GOx-Cyt $c @ \mathrm{Cu}(\mathrm{Im})_{2}$ can be used to detect low concentrations of glucose with excellent selectivity.

\section{Results and Discussion}

\subsection{Preparation and Characterization of Enzyme@Cu(Im)}

The preparation process of the composite material containing enzymes was shown in Figure S1. The synthesis of enzyme@ $\mathrm{Cu}(\operatorname{Im})_{2}$ was by mixing enzyme, dimethylimidazole $(\operatorname{Im})$ and $\mathrm{CuSO}_{4}$, and the incubation time was no less than $8 \mathrm{~h}$ to ensure adequate enzyme biomimetic mineralization. Using this procedure, we constructed both $\mathrm{Cyt} c @ \mathrm{Cu}(\mathrm{Im})_{2}$ and GOx-Cyt $c @ \mathrm{Cu}(\mathrm{Im})_{2}$. To remove non-encapsulated enzymes, all composite materials were centrifuged and washed with double distilled water for several times before vacuum freeze-drying. From Figure S2, it was observed that the encapsulated efficiency of enzymes was more than $99 \%$.

The as-prepared materials were characterized by various experimental methods. The scanning electron microscopy (SEM) was applied to obtain the morphology of the prepared materials. The microstructure of $\mathrm{Cu}(\mathrm{Im})_{2}$ presented interlaced sheets (Figure 1a), which were somewhat similar to previously reported cupric phosphate nano-flowers [33]. Moreover, these sheets slightly bended to form petals like in $\mathrm{Cyt} c @ \mathrm{Cu}(\operatorname{Im})_{2}$ (Figure 1b), similar to that of the pure $\mathrm{Cu}(\operatorname{Im})_{2}$. These observations suggest that $\mathrm{Cytc}$ has little effect on the structure and morphology of $\mathrm{Cu}(\mathrm{Im})_{2}$. In contrast, GOx-Cyt $c @ \mathrm{Cu}(\mathrm{Im})_{2}$ showed an uneven and porous morphology, similar to GOx@Cu(Im) $)_{2}$ (Figure S3), which is due to the coherent interactions of co-assembly between GOx and Cyt $c$. The X-ray diffraction (XRD) was performed for $\mathrm{Cu}(\operatorname{Im})_{2}$, and $\mathrm{Cyt} c @ \mathrm{Cu}(\operatorname{Im})_{2}$. As shown in Figure S4, the results showed that the characteristic diffraction peaks of prepared Cyt $c @ \mathrm{Cu}(\mathrm{Im})_{2}$ were almost the same as that of $\mathrm{Cu}(\mathrm{Im})_{2}$, indicating that the structure of $\mathrm{Cu}(\mathrm{Im})_{2}$ was almost not affected by the encapsulation of $\mathrm{Cyt} c$, which is in agreement with the results of SEM (Figure 1).

It is well known that protein molecules have typical Fourier transform infrared spectroscopy (FTIR) stretch characteristics at $1640-1660 \mathrm{~cm}^{-1}$ and $1510-1560 \mathrm{~cm}^{-1}$, which correspond to the $\mathrm{C}=\mathrm{O}$ stretching mode, $\mathrm{NH}$ bending and $\mathrm{CN}$ stretching modes on the peptide chain $[16,26]$. These characteristic peaks can be clearly identified in the Cyt $c$ and other composites of mineralizing enzymes (Figure 2a), but were absent in the material of $\mathrm{Cu}(\mathrm{Im})_{2}$ prepared in the absence of enzymes, indicating the incorporation of enzymes in the matrix of $\mathrm{Cu}(\mathrm{Im})_{2}$.

Thermal gravimetric analysis (TGA) under nitrogen atmosphere also confirmed the embedment of protein into the $\mathrm{Cu}(\mathrm{Im})_{2}$ (Figure $2 \mathrm{~b}$ ). In the range of less than $200^{\circ} \mathrm{C}$, the mass loss is mainly due to 
the loss of water and unreacted reagent [14]. The second decomposition stage was observed for all enzyme@Cu(Im) $)_{2}$ samples, 25.39\% (Cyt c@Cu(Im) $\left.)_{2}\right), 25.76 \%\left(\mathrm{GOx}-\mathrm{Cyt} c @ \mathrm{Cu}(\operatorname{Im})_{2}\right)$ between $200{ }^{\circ} \mathrm{C}$ and $370{ }^{\circ} \mathrm{C}$ (Table 1). This is attributed to thermal decomposition of the encapsulated enzymes [34], which further indicates the successful enzyme encapsulation.
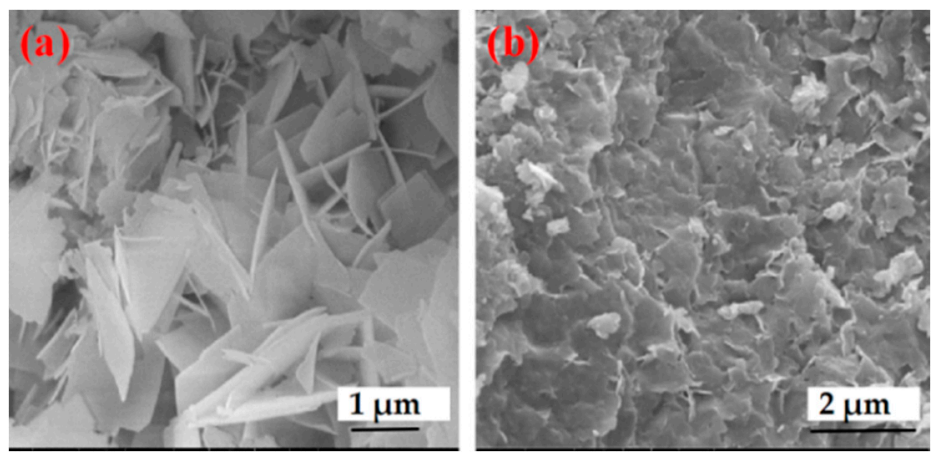

Figure 1. SEM images of $(\mathbf{a}) \mathrm{Cu}(\mathrm{Im})_{2}$ and $(\mathbf{b}) \mathrm{Cyt} c @ \mathrm{Cu}(\operatorname{Im})_{2}$.
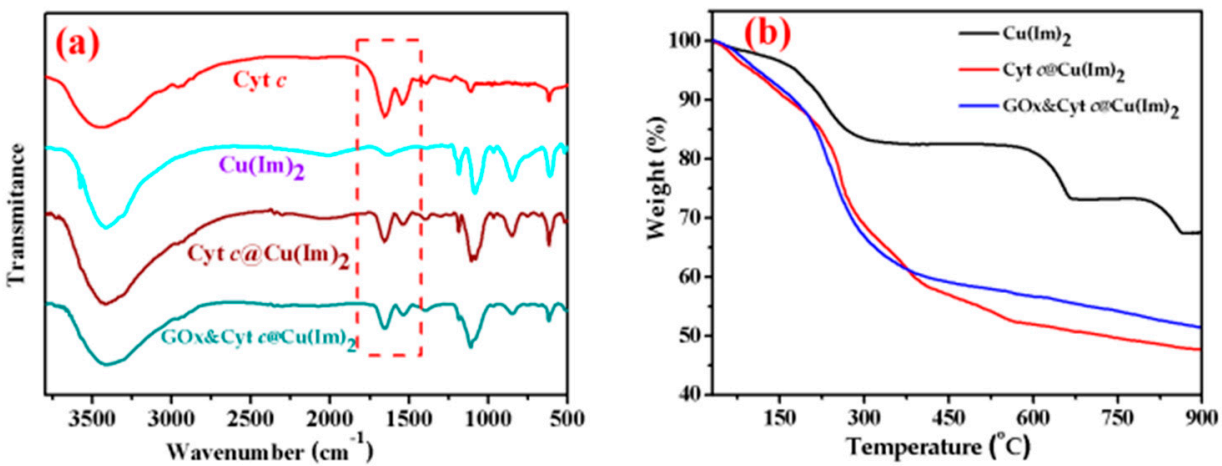

Figure 2. (a) FTIR spectra of Cyt $c, \mathrm{Cu}(\mathrm{Im})_{2}, \mathrm{Cyt} c @ \mathrm{Cu}(\mathrm{Im})_{2}$ and GOx-Cyt $c @ \mathrm{Cu}(\mathrm{Im})_{2} ;(\mathbf{b})$ TGA curves of $\mathrm{Cu}(\operatorname{Im})_{2}$, enzyme@ $\mathrm{Cu}(\operatorname{Im})_{2}$ in $\mathrm{N}_{2}$ atmosphere.

Table 1. Mass loss (\%) of $\mathrm{Cu}(\mathrm{Im})_{2}$ and enzyme@ $\mathrm{Cu}(\mathrm{Im})_{2}$ composite.

\begin{tabular}{cccc}
\hline Sample & $\begin{array}{c}\text { Mass Loss } \mathbf{( \% )} \\
\mathbf{T}<\mathbf{2 0 0}{ }^{\circ} \mathbf{C}\end{array}$ & $\begin{array}{c}\text { Mass Loss (\%) } \\
\mathbf{2 0 0}{ }^{\circ} \mathbf{C}<\mathbf{T}<\mathbf{3 7 0}{ }^{\circ} \mathbf{C}\end{array}$ & Total Mass Loss (\%) \\
\hline $\mathrm{Cu}(\mathrm{Im})_{2}$ & 6.99 & 10.48 & 32.46 \\
Cyt $c @ \mathrm{Cu}(\mathrm{Im})_{2}$ & 12.53 & 25.39 & 52.33 \\
GOx-Cyt $c @ \mathrm{Cu}(\mathrm{Im})_{2}$ & 12.61 & 25.76 & 49.58 \\
\hline
\end{tabular}

To further prove the embedment of enzymes into $\mathrm{Cu}(\mathrm{Im})_{2}$, fluorescence labeling assay was carried out by Delta Vision Elite high-resolution microscope. The Cyt $c$ and GOx were labeled using FITC and $\mathrm{RhB}$, respectively, and the labeled enzymes were encapsulated into $\mathrm{Cu}(\mathrm{Im})_{2}$ by using the same procedure. As shown in Figure 3, green, red and yellow-green fluorescence was observed for (FITC-GOx), (RhB-Cyt $c$ ) and (GOx-RhB-Cyt $c$-FITC@Cu(Im)2), respectively, which further indicates the successful encapsulation of single enzyme and multi-enzyme.

\subsection{Peroxidase Activity Assay of Free Cyt c and Cyt c@Cu(Im) 2}

The peroxidase catalytic activity of $\mathrm{Cyt} c @ \mathrm{Cu}(\mathrm{Im})_{2}$ was effected by various factors. For example, the $\mathrm{pH}$ value plays an important role in the enzymatic activity. The enzymes were severely inactivated under highly acidic or alkaline conditions. As shown in Figure S5a, Cyt $c @ \mathrm{Cu}(\mathrm{Im})_{2}$ showed the highest catalytic activity at $\mathrm{pH} 7.4$, which is different from that of free Cyt $c$ (at $\sim \mathrm{pH} 6.5$ ). Moreover, Cyt $c @ \mathrm{Cu}(\operatorname{Im})_{2}$ showed a higher catalytic activity compared to that of free Cyt $c$ under the same conditions 
as a result of biomineralization. For example, the catalytic reaction rate of $\mathrm{Cyt} c @ \mathrm{Cu}(\mathrm{Im})_{2}$ was faster than that of free enzyme (Figure 4a), which is consistent with the chromogenic reaction (Figure 4a, insert.)
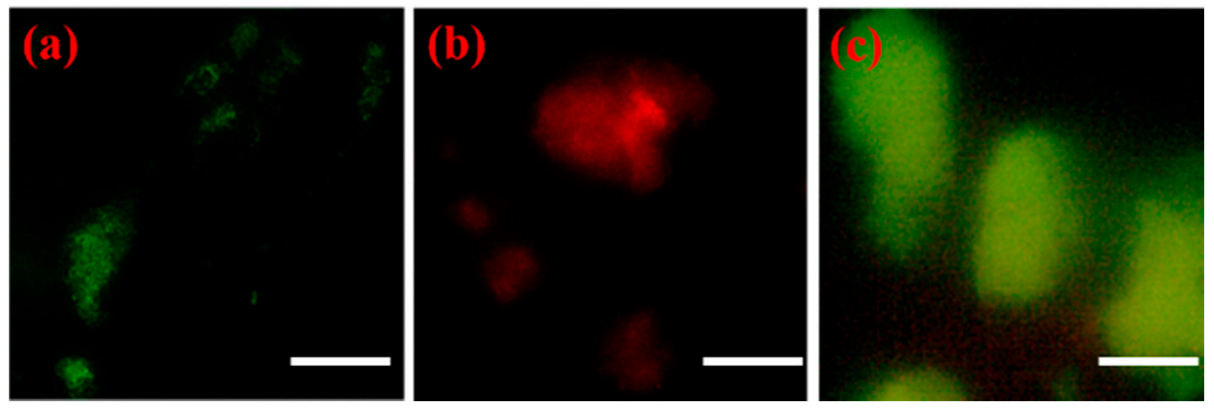

Figure 3. High resolution microscope image of (a) GOx@Cu(Im) $)_{2}-\mathrm{RhB}$, (b) Cyt $c @ \mathrm{Cu}(\mathrm{Im})_{2}-\mathrm{FITC}$ and (c) GOx-RhB and Cyt c-FITC@Cu(Im) 2 (scale bar is $15 \mu \mathrm{m}$ ).
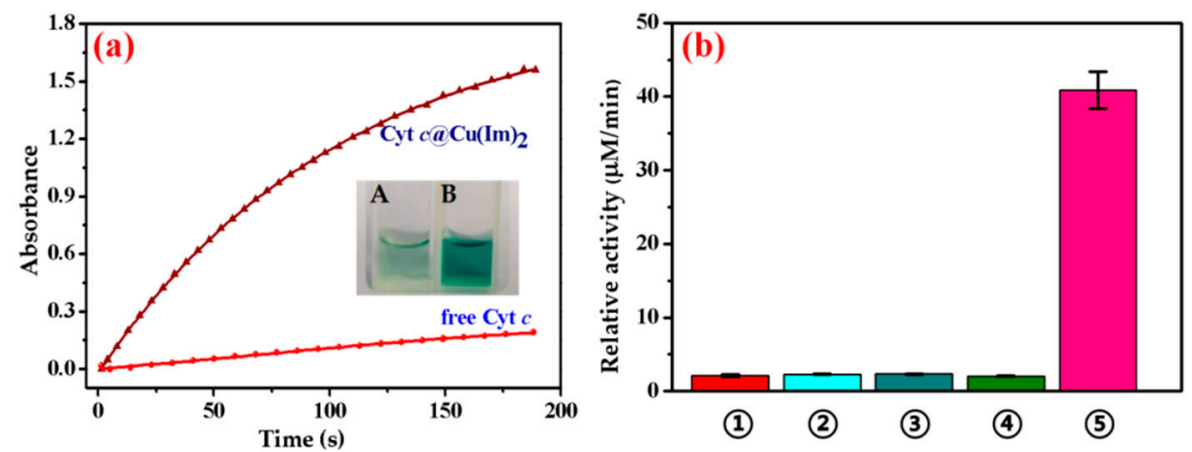

Figure 4. (a) The kinetic analysis of free Cyt $c$ and Cyt $c @ \mathrm{Cu}(\mathrm{Im})_{2}$, the chromogenic reaction of free Cyt $c$ (insert A) and Cyt $c @ \mathrm{Cu}(\mathrm{Im})_{2}$ (insert B); (b) The activity of (1) free Cyt c, (2) Cyt c/copper ion. (3) Cyt $c / \mathrm{Cu}(\operatorname{Im})_{2},(4) \mathrm{Cyt} c / \mathrm{Im}$ and (5) Cyt $c @ \mathrm{Cu}(\mathrm{Im})_{2}$, respectively.

Moreover, we prepared several non-mineralization composites, including Cyt $c$, Cyt $c / \mathrm{CuSO}_{4}, \mathrm{Cyt}$ $c / \mathrm{Cu}(\operatorname{Im})_{2}$ and $\mathrm{Cyt} c / \mathrm{Im}$. The experimental results showed these materials had poor catalytic efficiency compared to biomimetic mineralization under the same experimental conditions, which elucidated that the mineralization process was important to improve the catalytic activity of Cyt $c$. This observation was consistent with that reported by Jianget al. [26]. The reason for the catalytic efficiency $\left(k_{\text {cat }} / K_{\mathrm{m}}\right)$ increased from 35.7 to $705 \mathrm{M}^{-1} \mathrm{~s}^{-1}$ (Table 2) might be the formation of a bimetallic center provided by $\mathrm{Cu}(\mathrm{Im})_{2}$ and the ferric porphyrin of Cyt $c[5,35]$, or a new catalytic site formed by $\mathrm{Cu}(\mathrm{Im})_{2}$ and coordinating amino acids on the protein surface [5].

Table 2. Kinetic parameters for free enzyme Cyt $c$, and Cyt $c @ \mathrm{Cu}(\operatorname{Im})_{2}$.

\begin{tabular}{cccc}
\hline Sample & $\boldsymbol{k}_{\text {cat }}\left(\mathbf{s}^{-\mathbf{1}}\right)$ & $\boldsymbol{K}_{\mathbf{m}}(\mathbf{m M})$ & $\boldsymbol{k}_{\text {cat }} / \boldsymbol{K}_{\mathbf{m}}\left(\mathbf{M}^{-\mathbf{1}} \mathbf{s}^{-\mathbf{1}}\right)$ \\
\hline Cyt $c$ & $0.75 \pm 0.17$ & $21 \pm 5$ & 35.7 \\
Cyt $c @ \mathrm{Cu}(\operatorname{Im})_{2}$ & $7.05 \pm 0.67$ & $10 \pm 1$ & 705 \\
\hline
\end{tabular}

\subsection{Peroxidase Activity Assay of Free GOx and Cyt c, and GOx-Cyt c@Cu(Im)}

Based on the composite of Cyt $c @ \mathrm{Cu}(\mathrm{Im})_{2}$, we also constructed a multi-enzyme system of GOx-Cyt $c @ \mathrm{Cu}(\mathrm{Im})_{2}$ using asimilar procedureas for a single enzyme. In addition, we investigated its enzymatic activity and cascade reaction efficiency, usingABTS as a typical chromogenic substrate. The glucose was catalyzed by $\mathrm{GOx}$ to generate $\mathrm{H}_{2} \mathrm{O}_{2}$ and gluconic acid, and then ABTS was oxidized by Cytc to form $\mathrm{ABTS}^{+\cdot}$ in presence of $\mathrm{H}_{2} \mathrm{O}_{2}$. Therefore, the enzymatic activity could be detected by measuring 
the absorbance of $\mathrm{ABTS}^{+}$by UV-vis spectroscopy at $420 \mathrm{~nm}$. The influence of $\mathrm{pH}(4.0-10.0)$ on the enzymatic activities of free GOx and Cyt $c$, and GOx-Cyt $c @ \mathrm{Cu}(\mathrm{Im})_{2}$ was investigated to optimize the reaction conditions. As shown in Figure S5b, the maximal enzymatic activity for $\mathrm{pH}$ of GOx and Cyt $c$, and GOx-Cyt $c @ \mathrm{Cu}(\mathrm{Im})_{2}$ was observed at 6.0 and 7.4, respectively. Since the enzymatic activity and cascade reaction efficiency were influenced by the molar ratio of enzymes, we herein chose the mass ratio of GOx and Cyt $c$ of 1:1 by optimization. Enzymatic activity increased with an increasing amount of Cyt $c$, which might be due to the rapid consumption of the produced $\mathrm{H}_{2} \mathrm{O}_{2}$. Nevertheless, the excess amount of Cyt $c$ could reduce the enzymatic activity, and the reason might be the high concentration of Cyt $c$ could suppress the activity of the system.

Under optimal conditions, the kinetic parameters of free GOx and Cyt $c$, and GOx-Cyt $c @ C u(\operatorname{Im})_{2}$ were determined to evaluate the enzymatic performance of the multi-enzyme. As shown in Figure 5a, GOx-Cyt $c @ \mathrm{Cu}(\mathrm{Im})_{2}$ has an obvious activation stage in the first minute of the reaction, whereas the free GOx-Cyt $c$ showed a premature inactivation. The $K_{\mathrm{m}}$ value was determined to be $6.39 \mathrm{mM}$ for GOx-Cyt $c @ \mathrm{Cu}(\mathrm{Im})_{2}$, indicating that the mineralized multi-enzyme of GOx-Cyt $c @ \mathrm{Cu}(\mathrm{Im})_{2}$ has a high affinity for the substrate. This is due toexcellent adsorption of mesoporous structure [36], which is consistent with the morphology shown in the SEM image (Figure 1$)$. Moreover, the catalytic efficiency $\left(k_{\text {cat }} / K_{\mathrm{m}}\right)$ was determined to be $413.2 \mathrm{M}^{-1} \mathrm{~s}^{-} 1$ for GOx-Cyt $c @ \mathrm{Cu}(\mathrm{Im})_{2}$, which was $\sim 6$-fold higher than that of free enzymes (Table 3). This corresponded to the chromogenic reaction of GOx and Cyt $c$ (Figure 5a, insert A) and GOx-Cyt $c @ \mathrm{Cu}(\operatorname{Im})_{2}$ (Figure 5a, insert B), which elucidates that GOx-Cyt $c @ C u(\operatorname{Im})_{2}$ shows a deeper color than that of free enzyme. The higher enzymatic activity of GOx-Cyt $c @ C u(\operatorname{Im})_{2}$ is attributed to a rapid activation of $\mathrm{H}_{2} \mathrm{O}_{2}$ generated in the multi-enzyme system by the cooperation of the two enzymes (Figure 5b).
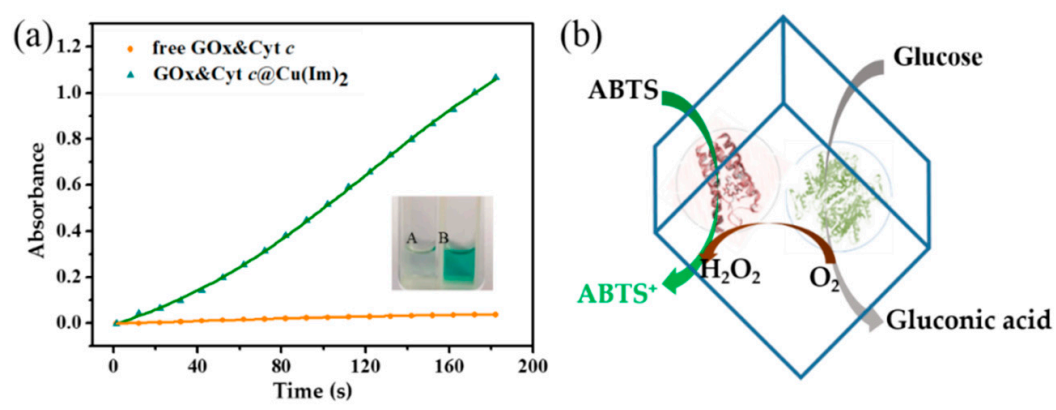

Figure 5. (a) Kinetic performance for GOx and Cyt $c$, and GOx-Cyt $c @ \mathrm{Cu}(\mathrm{Im})_{2}$, and the chromogenic reactions of GOx and $\mathrm{Cyt} c$, and GOx-Cyt $c @ \mathrm{Cu}(\mathrm{Im})_{2}$ were shown as insets A and B, respectively; (b) Schematic diagram of GOx-Cyt $c @ \mathrm{Cu}(\mathrm{Im})_{2}$ catalyzing ABTS in the presence of glucose.

Table 3. Kinetic parameters of GOx in free GOx and Cyt $c$, and GOx-Cyt $c @ C u(\operatorname{Im})_{2}(\mathrm{mG}: \mathrm{mC}=1)$.

\begin{tabular}{cccc}
\hline Sample & $\boldsymbol{k}_{\text {cat }}\left(\mathbf{s}^{\mathbf{- 1}}\right)$ & $\boldsymbol{K}_{\mathbf{m}}(\mathbf{m M})$ & $\boldsymbol{k}_{\text {cat }} / \boldsymbol{K}_{\mathbf{m}}\left(\mathbf{M}^{\mathbf{- 1}} \mathbf{s}^{\mathbf{- 1}}\right)$ \\
\hline GOx-Cyt $c$ & $0.09 \pm 0.01$ & $1.30 \pm 0.14$ & 69.2 \\
GOx-Cyt $c @ C u(\operatorname{Im})_{2}$ & $2.64 \pm 0.24$ & $6.39 \pm 0.57$ & 413.2 \\
\hline
\end{tabular}

\subsection{Stability and Reusability}

Usually, free enzyme in aqueous solution can produce an unpleasant smell due to protein putrefaction upon long-term storage. In this study, we found that the activity of both Cyt $c @ \mathrm{Cu}(\operatorname{Im})_{2}$, and GOx-Cyt c@Cu(Im) $)_{2}$ remained 100\% after storage at $4{ }^{\circ} \mathrm{C}$ and at room temperature (RT) for a week (Figure 6a), which indicates that bioinorganic material $\mathrm{Cu}(\mathrm{Im})_{2}$ provides excellent protection for enzymes. The reusability of $\mathrm{Cyt} c @ \mathrm{Cu}(\mathrm{Im})_{2}$ was determined to further assess the immobilized enzyme performance. As shown in Figure 6b, Cyt $c @ \mathrm{Cu}(\operatorname{Im})_{2}$ still preserved more than $35 \%$ of the original activity after five cycles. The results showed that although the biocatalyst was less stable to recycle, they were more stable upon storage. 
In addition, we investigated the stability of free and immobilized enzyme against high temperature and organic solvents. The results showed that $\mathrm{Cyt} c @ \mathrm{Cu}(\mathrm{Im})_{2}$ preserved the same original enzymatic activity aftertreatment of heating at $70{ }^{\circ} \mathrm{C}$ or incubation with ethanol (Figure S6). Theseobservations indicated that inorganic material $\mathrm{Cu}(\mathrm{Im})_{2}$ can protect the encapsulated enzyme from degradation or inactivation by organic solvents.
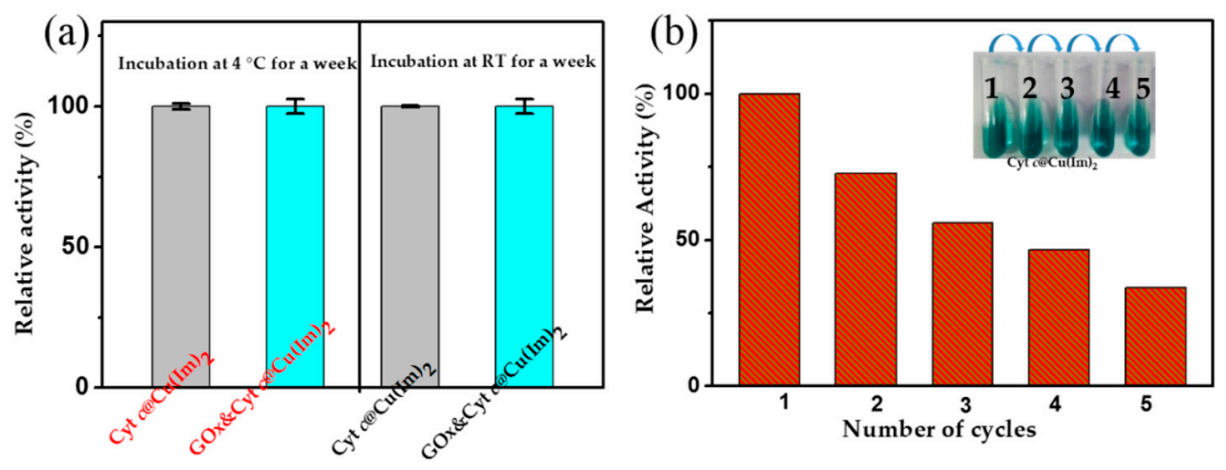

Figure 6. (a) Stability for Cyt $c @ \mathrm{Cu}(\operatorname{Im})_{2}$ and $\mathrm{GOx}-\mathrm{Cyt} c @ \mathrm{Cu}(\mathrm{Im})_{2}$ against long-term placing; (b) Reusability of $\mathrm{Cyt} c @ \mathrm{Cu}(\mathrm{Im})_{2}$.

\subsection{Glucose Detection}

The catalytic performance of the GOx-Cyt $c @ \mathrm{Cu}(\mathrm{Im})_{2}$ was evaluated by the detection of glucose in KPi buffer (40 mM, pH 7.4). As shown in Figure 7a, an excellent linearity $(y=0.0082 x+0.0371$, $\mathrm{R}^{2}=0.9921$ ) between the absorbance and the concentration of glucose in the range of 2.5 to $150 \mu \mathrm{M}$ was obtained. The limit-of-detection (LOD) of glucose was calculated to be $0.7 \mu \mathrm{M}$, which was lower than most of the reported colorimetric glucose sensors [37,38]. The reason for high activity and sensitivity toward detection of glucose was the more efficient activation of the intermediate product $\left(\mathrm{H}_{2} \mathrm{O}_{2}\right)$. Moreover, we studied the selectivity of GOx-Cyt $c @ \mathrm{Cu}(\mathrm{Im})_{2}$ toward glucose against various analogs, including fructose, mannose, xylose, lactose, galactose, sucrose and galactose. Although the concentration of the interfering compounds (mentioned above) was 10-times higher than that of glucose, a negligible enzymatic activity toward these competing compounds was found (Figure 7b), suggesting the high selectivity toward glucose.
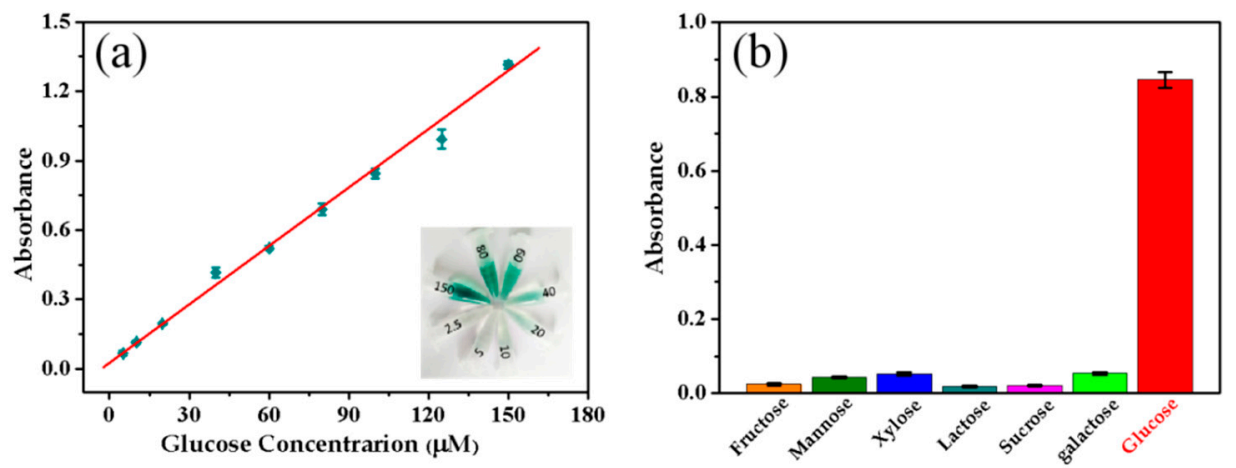

Figure 7. (a) Linear correlation for glucose $(2.5-150 \mu \mathrm{M})$ detection; (b) Selectivityfor glucose $(100 \mu \mathrm{M})$ detection with interfering compounds (1.0 mM offructose, mannose, xylose, lactose, galactose, sucrose, and galactose).

\section{Materials and Methods}

\subsection{Materials and Instruments}

Cytochrome $c$ from equine heart (oxidation state, petal-like crystal) and glucoseoxidase (50 ku, Roche subpackage) were purchased from Regal (Shanghai, China). Rhodamine B isothiocyanate 
(RhB) was from Hefei Ruibio (Hefei, China), 2-methylimidazole (Im) was obtained from Adamas-beta (Shanghai, China). D-glucose was from Kermerl Corporation (Tianjin, China). Fluoresceinisothiocyanate (FITC), ABTS [2,2'-Azinobis (3-ethylbenzothiazoline-6-sulfonic Acid Ammonium Salt], xylose, fructose, galactose, lactose, mannose and sucrose were purchased from Aladdin (Shanghai, China). All other reagents were of analytical grade, which include $\mathrm{CuSO}_{4} \cdot 5 \mathrm{H}_{2} \mathrm{O}, \mathrm{KH}_{2} \mathrm{PO}_{4}, \mathrm{KOH}$ and $\mathrm{H}_{2} \mathrm{O}_{2}$.

SEM images were obtained on FEI HELIOS NanoLab 600i SEM (Hillsboro, OR, USA). UV-Vis spectral measurements were recorded on a Hewlett-Packard 8453 diode array spectrometer. XRD patternsof various samples were obtained from Bruker D8 Advance (Billerica, MA, USA), AXS and TGA experiments were performed by using STA2500, NETZSCH-Gerätebau GmbH. High-resolution microscope imageswere obtained by using a high-resolution microscope (Delta Vision Elite, GE, Boston, MA, USA).

\subsection{Preparation of Enzyme@ Cu(Im) 2}

Cyt $c @ \mathrm{Cu}(\mathrm{Im})_{2}$ was prepared by mixing Cyt $c(0.4 \mathrm{mg} / \mathrm{mL}, 2 \mathrm{~mL}), \operatorname{Im}(160 \mathrm{mM}, 1 \mathrm{~mL})$ with $\mathrm{CuSO}_{4}$ solution $(40 \mathrm{mM}, 1 \mathrm{~mL})$ and incubating for $8 \mathrm{~h}$. GOx-Cyt $c @ \mathrm{Cu}(\mathrm{Im})_{2}$ was obtained by a similar process except for replacing Cyt $c(0.4 \mathrm{mg} / \mathrm{mL}, 2 \mathrm{~mL})$ with $1 \mathrm{~mL} 0.4 \mathrm{mg} / \mathrm{mL}$ Cyt $c$ and $1 \mathrm{~mL} 0.4 \mathrm{mg} / \mathrm{mL}$ GOx. The encapsulated enzymes were centrifuged ( $4000 \mathrm{rpm}, 1 \mathrm{~min}$ ) and washed with double distilled water three times.

\subsection{Fluorescent Labeling of Enzymes}

Fluorescent labeling of enzymes was carried out by dripping a small amount of FITC and RhBisothiocyanate into Cyt $c$ and GOx solutions, respectively, and then incubating them for $15 \mathrm{~h}$ in the refrigerator of $4{ }^{\circ} \mathrm{C}$. In order to remove uncoupled fluorescent substances, the mixtures were centrifuged (4000 rpm, $15 \mathrm{~min}$ ) with Amicon ${ }^{\circledR}$ Ultra-4 $10 \mathrm{~K}$ centrifugal filter devices (Sigma-Aldrich, Saint Louis, MO, USA) several times. Finally, the mineralization process is similar to that of Cyt $c @ \mathrm{Cu}(\operatorname{Im})_{2}$.

\subsection{Peroxidase Activity Assay}

Peroxidase activity assays for $\mathrm{Cyt} c @ \mathrm{Cu}(\mathrm{Im})_{2}$ was added into $\mathrm{KPi}(\mathrm{pH} 7.4,40 \mathrm{mM})$ containing $1 \mathrm{mM}$ ABTS, then adding $\mathrm{H}_{2} \mathrm{O}_{2}$, and the final volume was $1 \mathrm{~mL}$. The dynamic reaction was determined by UV-vis and the absorbance at $420 \mathrm{~nm}$ was recorded for $3 \mathrm{~min}$. The enzyme activity assay of free Cyt $c$ was the same as that of $\mathrm{Cyt} c @ \mathrm{Cu}(\mathrm{Im})_{2}$ under the same conditions.

Peroxidase activity assays for GOx-Cyt $c @ \mathrm{Cu}(\mathrm{Im})_{2}$ was added into $1 \mathrm{~mL}$ of $\mathrm{KPi}(\mathrm{pH} 7.4,40 \mathrm{mM})$ containing glucose with different concentrations $(0-10 \mathrm{mM}), 1 \mathrm{mM}$ ABTS. The dynamic reaction was determined by UV-vis and the absorbance at $420 \mathrm{~nm}$ was recorded for $3 \mathrm{~min}$. The limit-of-detection (LOD) was calculated by using a formula of LOD $=3 \mathrm{~S} / \mathrm{N}$, whereS and $\mathrm{N}$ represent the standard deviation of the regression line for three independent measurements, and the Slope, respectively. The enzyme activity assay of free GOx and Cyt $c$ was the same as that of GOx-Cyt $c @ C u(I m)_{2}$ under the same conditions.

\subsection{Enzyme Stability Test}

The storage stability of Cyt $c @ \mathrm{Cu}(\mathrm{Im})_{2}$ and GOx-Cyt $c @ \mathrm{Cu}(\mathrm{Im})_{2}$ continued to hatch at $4{ }^{\circ} \mathrm{C}$ and room temperature for a week. Cyt $c @ \mathrm{Cu}(\mathrm{Im})_{2}$ was reused at $25^{\circ} \mathrm{C}$ for $5 \mathrm{~min}$ in $100 \mathrm{mM} \mathrm{KPi}(\mathrm{pH}$ 7.4) to evaluate the reusability.

\section{Conclusions}

In summary, we have constructed a highly active enzyme-inorganic composite material by biomimetic mineralization. The prepared Cyt $c @ C u(I m)_{2}$ exhibits excellent catalytic efficiency, long-term storage stability, and reusability, as compared to the free enzyme, which demonstrates that the 
mineralization could well maintain and fix the conformation of protein. Moreover, we have introduced GOx into Cyt $c @ \mathrm{Cu}(\mathrm{Im})_{2}$ to develop multi-enzyme system of GOx-Cyt $c @ \mathrm{Cu}(\mathrm{Im})_{2}$. As designed, this multi-enzyme exhibits an improved enzymatic activity. The cascade reaction of GOx-Cyt $c @ \mathrm{Cu}(\mathrm{Im})_{2}$ was used to detect low concentrations $(2.5$ to $150 \mu \mathrm{M}$ ) of glucose with excellent selectivity (LOD of $0.7 \mu \mathrm{M})$. Therefore, the multi-enzyme system constructed in this study may confer potential applications in biocatalysis and biosensors, etc.

Supplementary Materials: The following are available online at http://www.mdpi.com/2073-4344/9/8/648/s1. Figure S1: The preparation process of Cyt $c @ \mathrm{Cu}(\mathrm{Im})_{2}$, and GOx-Cyt $c @ \mathrm{Cu}(\mathrm{Im})_{2}$, Figure S2: UV-Vis spectra of free Cyt $c$ before encapsulation (red) and the supernatant of Cyt $c$ after encasing in $\mathrm{Cu}(\mathrm{Im})_{2}$ (black), Figure S3: SEM images of the GOx@Cu(Im) 2 and GOx-Cyt $c @ C u(\operatorname{Im})_{2}$, Figure S4: X-ray diffraction (XRD) patterns of the $\mathrm{Cu}(\mathrm{Im})_{2}$, Cyt $c @ \mathrm{Cu}(\mathrm{Im})_{2}, \mathrm{GOx} @ \mathrm{Cu}(\mathrm{Im})_{2}$, and GOx-Cyt $c @ \mathrm{Cu}(\mathrm{Im})_{2}$, Figure S5: The effect of pH on activity of (a) Cyt $c$ and Cyt $c @ \mathrm{Cu}(\mathrm{Im})_{2}$, (b) GOx-Cyt $c$, and GOx-Cyt $c @ \mathrm{Cu}(\mathrm{Im})_{2}$, Figure S6: Relative activities of Cyt $c @ \mathrm{Cu}(\mathrm{Im})_{2}$ after water bath at $70{ }^{\circ} \mathrm{C}$ and incubation in ethanol for $0.5 \mathrm{~h}$.

Author Contributions: X.-J.W. and Y.-W.L. designed the project. X.-Q.G., C.-W.W. J.-K.X., and S.-Q.G. performed the experiments. X.-Q.G., C.-W.W., J.-K.X., X.-J.W. and Y.-W.L. analyzed the data. X.-Q.G., X.-J.W. and Y.-W.L. organized the experimental results and wrote the manuscript.

Funding: This work was supported by the National Natural Science Foundation of China (21807058), Special Scientific Research Funds for Central Non-profit Institutes, Yellow Sea Fisheries Research Institute, Chinese Academy of Fishery Sciences (20603022016011), Financial Fund of the Ministry of Agriculture and Rural Affairs, P. R. of China (NFZX2018), the Marine S\&T Fund of Shandong Province for Pilot National Laboratory for Marine Science and Technology (Qingdao) (2018SDKJ0304-4-2), Hunan Provincial Natural Science Foundation (2019JJ50492, 2019JJ40259), Hunan Provincial Education Foundation (18C0420), and the Doctoral scientific research foundation of the University of South China (2014XQD32, 2017XQD10).

Conflicts of Interest: The authors declare no conflict of interest.

\section{References}

1. Lu, Y.; Yeung, N.; Sieracki, N.; Marshall, N.M. Design of functional metalloproteins. Nature 2009, 460, 855-862. [CrossRef] [PubMed]

2. Poulos, T.L. Heme enzyme structure and function. Chem. Rev. 2014, 114, 3919-3962. [CrossRef] [PubMed]

3. Mirts, E.N.; Bhagi-Damodaran, A.; Lu, Y. Understanding and Modulating Metalloenzymes with Unnatural Amino Acids, Non-Native Metal Ions, and Non-Native Metallocofactors. Acc. Chem. Res. 2019, 52, 935-944. [CrossRef] [PubMed]

4. Hirota, S.; Lin, Y.-W. Design of artificial metalloproteins/metalloenzymes by tuning noncovalent interactions. J. Biol. Inorg. Chem. 2018, 23, 7-25. [CrossRef] [PubMed]

5. Lin, Y.-W. Rational design of metalloenzymes: From single to multiple active sites. Coord. Chem. Rev. 2017, 336, 1-27. [CrossRef]

6. Yin, L.-L.; Yuan, H.; Liu, C.; He, B.; Gao, S.-Q.; Wen, G.-B.; Tan, X.; Lin, Y.-W. A Rationally Designed Myoglobin Exhibits a Catalytic Dehalogenation Efficiency More than 1000-Fold That of a Native Dehaloperoxidase. ACS Catal. 2018, 8, 9619-9624. [CrossRef]

7. Liu, C.; Yuan, H.; Liao, F.; Wei, C.-W.; Du, K.-J.; Gao, S.-Q.; Tan, X.; Lin, Y.-W. Unique Tyr-heme double cross-links in F43Y/T67R myoglobin: An artificial enzyme with a peroxidase activity comparable to that of native peroxidases. Chem. Commun. 2019, 55, 6610-6613. [CrossRef] [PubMed]

8. Lin, Y.-W. Rational design of heme enzymes for biodegradation of pollutants towards a green future. Biotechnol. Appl. Biochem. 2019. [CrossRef] [PubMed]

9. Li, P.; Moon, S.Y.; Guelta, M.A.; Harvey, S.P.; Hupp, J.T.; Farha, O.K. Encapsulation of a Nerve Agent Detoxifying Enzyme by a Mesoporous Zirconium Metal-Organic Framework Engenders Thermal and Long-Term Stability. J. Am. Chem. Soc. 2016, 138, 8052-8055. [CrossRef]

10. Majewski, M.B.; Howarth, A.J.; Li, P.; Wasielewski, M.R.; Hupp, J.T.; Farha, O.K. Enzyme encapsulation in metal-organic frameworks for applications in catalysis. CrystEngComm 2017, 19, 4082-4091. [CrossRef]

11. Hu, Y.; Dai, L.; Liu, D.; Du, W.; Wang, Y. Progress \& prospect of metal-organic frameworks (MOFs) for enzyme immobilization (enzyme/MOFs). Renew. Sustain. Energy Rev. 2018, 91, 793-801. 
12. Khoshnevisan, K.; Vakhshiteh, F.; Barkhi, M.; Baharifar, H.; Poor-Akbar, E.; Zari, N.; Stamatis, H.; Bordbar, A.-K. Immobilization of cellulase enzyme onto magnetic nanoparticles: Applications and recent advances. Mol. Catal. 2017, 442, 66-73. [CrossRef]

13. Gascón, V.; Carucci, C.; Jiménez, M.B.; Blanco, R.M.; Sánchez-Sánchez, M.; Magner, E. Rapid In Situ Immobilization of Enzymes in Metal-Organic Framework Supports under Mild Conditions. ChemCatChem 2017, 9, 1182-1186. [CrossRef]

14. Naseri, M.; Pitzalis, F.; Carucci, C.; Medda, L.; Fotouhi, L.; Magner, E.; Salis, A. Lipase and Laccase Encapsulated on Zeolite Imidazolate Framework: Enzyme Activity and Stability from Voltammetric Measurements. Chem CatChem 2018, 10, 5425-5433. [CrossRef]

15. Liang, K.; Ricco, R.; Doherty, C.M.; Styles, M.J.; Bell, S.; Kirby, N.; Mudie, S.; Haylock, D.; Hill, A.J.; Doonan, C.J.; et al. Biomimetic mineralization of metal-organic frameworks as protective coatings for biomacromolecules. Nature Commun. 2015, 6, 7240. [CrossRef] [PubMed]

16. Li, Z.; Ding, Y.; Li, S.; Jiang, Y.; Liu, Z.; Ge, J. Highly active, stable and self-antimicrobial enzyme catalysts prepared by biomimetic mineralization of copper hydroxysulfate. Nanoscale 2016, 8, 17440-17445. [CrossRef] [PubMed]

17. Liang, W.; Ricco, R.; Maddigan, N.K.; Dickinson, R.P.; Xu, H.; Li, Q.; Sumby, C.J.; Bell, S.G.; Falcaro, P.; Doonan, C.J. Control of Structure Topology and Spatial Distribution of Biomacromolecules in Protein@ZIF-8 Biocomposites. Chem. Mater. 2018, 30, 1069-1077. [CrossRef]

18. Maddigan, N.K.; Tarzia, A.; Huang, D.M.; Sumby, C.J.; Bell, S.G.; Falcaro, P.; Doonan, C.J. Protein surface functionalisation as a general strategy for facilitating biomimetic mineralisation of ZIF-8. Chem. Sci. 2018, 9, 4217-4223. [CrossRef]

19. Wu, J.; Wang, X.; Wang, Q.; Lou, Z.; Li, S.; Zhu, Y.; Qin, L.; Wei, H. Nanomaterials with enzyme-like characteristics (nanozymes): Next-generation artificial enzymes. Chem. Soc. Rev. 2019, 48, 1004-1076. [CrossRef]

20. Bertini, I.; Cavallaro, G.; Rosato, A. Cytochrome c: Occurrence and functions. Chem. Rev. 2006, 106, 90-115. [CrossRef]

21. Ying, T.; Wang, Z.H.; Lin, Y.W.; Xie, J.; Tan, X.; Huang, Z.X. Tyrosine-67 in cytochrome c is a possible apoptotic trigger controlled by hydrogen bonds via a conformational transition. Chem. Commun. 2009, 4512-4514. [CrossRef]

22. Sun, M.-H.; Liu, S.-Q.; Du, K.-J.; Nie, C.-M.; Lin, Y.-W. A spectroscopic study of uranyl-cytochrome b5/cytochrome c interactions. Spectrochim. Acta A. Mol. Biomol. Spectrosc. 2014, 118, 130-137. [CrossRef]

23. Wang, X.; Wei, C.; Su, J.-H.; He, B.; Wen, G.-B.; Lin, Y.-W.; Zhang, Y. A Chiral Ligand Assembly That Confers One-Electron O2 Reduction Activity for a Cu2+-Selective Metallohydrogel. Angew. Chem. Int. Ed. 2018, 57, 3504-3508. [CrossRef]

24. Wu, X.; Yang, C.; Ge, J. Green synthesis of enzyme/metal-organic framework composites with high stability in protein denaturing solvents. Bioresour. Biopro. 2017, 4, 24. [CrossRef]

25. Lyu, F.; Zhang, Y.; Zare, R.N.; Ge, J.; Liu, Z. One-pot synthesis of protein-embedded metal-organic frameworks with enhanced biological activities. Nano Lett. 2014, 14, 5761-5765. [CrossRef]

26. Li, Z.; Xia, H.; Li, S.; Pang, J.; Zhu, W.; Jiang, Y. In situ hybridization of enzymes and their metal-organic framework analogues with enhanced activity and stability by biomimetic mineralisation. Nanoscale 2017, 9, 15298-15302. [CrossRef]

27. Sun, J.; Ge, J.; Liu, W.; Lan, M.; Zhang, H.; Wang, P.; Wang, Y.; Niu, Z. Multi-enzyme co-embedded organic-inorganic hybrid nanoflowers: Synthesis and application as a colorimetric sensor. Nanoscale 2014, 6, 255-262. [CrossRef]

28. Garny, S.; Beeton-Kempen, N.; Gerber, I.; Verschoor, J.; Jordaan, J. The co-immobilization of P450-type nitric oxide reductase and glucose dehydrogenase for the continuous reduction of nitric oxide via cofactor recycling. Enzyme Microb. Technol. 2016, 85, 71-81. [CrossRef]

29. Chen, Q.; Liu, D.; Wu, C.; Yao, K.; Li, Z.; Shi, N.; Wen, F.; Gates, I.D. Co-immobilization of cellulase and lysozyme on amino-functionalized magnetic nanoparticles: An activity-tunable biocatalyst for extraction of lipids from microalgae. Bioresour. Technol. 2018, 263, 317-324. [CrossRef]

30. Jin, X.; Li, S.; Long, N.; Zhang, R. A robust and stable nano-biocatalyst by co-immobilization of chloroperoxidase and horseradish peroxidase for the decolorization of azo dyes. J. Chem. Technol. Biotechnol. 2018, 93, 489-497. [CrossRef] 
31. Rocha-Martín, J.; Rivas, B.D.L.; Muñoz, R.; Guisán, J.M.; López-Gallego, F. Rational Co-Immobilization of Bi-Enzyme Cascades on Porous Supports and their Applications in Bio-Redox Reactions with In Situ Recycling of Soluble Cofactors. ChemCatChem 2012, 4, 1279-1288. [CrossRef]

32. Yu, M.; Liu, D.; Sun, L.; Li, J.; Chen, Q.; Pan, L.; Shang, J.; Zhang, S.; Li, W. Facile fabrication of 3D porous hybrid sphere by co-immobilization of multi-enzyme directly from cell lysates as an efficient and recyclable biocatalyst for asymmetric reduction with coenzyme regeneration in situ. Int. J. Biol. Macromol. 2017, 103, 424-434. [CrossRef]

33. He, G.; Hu, W.; Li, C.M. Spontaneous interfacial reaction between metallic copper and PBS to form cupric phosphate nanoflower and its enzyme hybrid with enhanced activity. Colloids Surf. B. 2015, 135, 613-618. [CrossRef]

34. Pan, Y.; Liu, Y.; Zeng, G.; Zhao, L.; Lai, Z. Rapid synthesis of zeoliticimidazolate framework-8 (ZIF-8) nanocrystals in an aqueous system. Chem. Commun. 2011, 47, 2071-2073. [CrossRef]

35. Kitagishi, H.; Shimoji, D.; Ohta, T.; Kamiya, R.; Kudo, Y.; Onoda, A.; Hayashi, T.; Weiss, J.; Wytko, J.A.; Kano, K. A water-soluble supramolecular complex that mimics the heme/copper hetero-binuclear site of cytochrome c oxidase. Chem. Sci. 2018, 9, 1989-1995. [CrossRef]

36. Zhang, C.; Wang, X.; Hou, M.; Li, X.; Wu, X.; Ge, J. Immobilization on Metal-Organic Framework Engenders High Sensitivity for Enzymatic Electrochemical Detection. ACS Appl. Mater. Inter. 2017, 9, 13831-13836. [CrossRef]

37. Shi, L.; Cai, X.; Li, H.; He, H.; Zhao, H.; Lan, M. ZIF-67 Derived Porous Carbon from Calcination and Acid Etching Process as an Enzyme Immobilization Platform for Glucose Sensing. Electroanalysis 2018, 30, 466-473. [CrossRef]

38. Aghayan, M.; Mahmoudi, A.; Nazari, K.; Dehghanpour, S.; Sohrabi, S.; Sazegar, M.R.; MohammadianTabrizi, N. Fe(III) porphyrin metal-organic framework as an artificial enzyme mimics and its application in biosensing of glucose and $\mathrm{H}_{2} \mathrm{O}_{2}$. J. Porous Mat. 2019. [CrossRef]

(C) 2019 by the authors. Licensee MDPI, Basel, Switzerland. This article is an open access article distributed under the terms and conditions of the Creative Commons Attribution (CC BY) license (http://creativecommons.org/licenses/by/4.0/). 